\title{
Strength Characteristics of High Performance Concrete using Bagasse Ash and Slag Sand
}

\author{
Latha M S ${ }^{1}$, Naveen Kumar B $\mathbf{M}^{2}$, Revanasiddappa Madihalli³, Deepika $\mathbf{R}^{4}$, Rudraswamy M $\mathbf{P}^{\mathbf{5}}$ \\ 1Professor, Civil Engineering Dept, Sri Venkateshwara College of Engineering, Affiliated to VTU, Bangalore \\ ${ }^{2,3}$ Assistant Professor, Civil Engineering Dept, Sri Venkateshwara College of Engineering, Affiliated to VTU, Bangalore \\ ${ }^{4}$ Assistant Professor, Civil Engineering Dept, R R Institute of Technology, Affiliated to VTU, Bangalore \\ ${ }^{5}$ Assistant Professor, Civil Engineering Dept, Vivekananda Institute of Technology, Affiliated to VTU, Bangalore
}

\begin{abstract}
Today the high demand in industry is fast construction owning to the properties of strength and high durability. Over the years' concrete has seen progressive development with respect to high performance. High performance concrete (HPC) due to its own property is been largely used for construction of global infrastructure such as bridges, dams, roads etc. The main aspect of the work is to check the durability and strength of HPC. In this study, an investigation is performed to develop high performance concrete using waste materials like Bagasse ash and slag sand - from different industries - with different percentage. Cement is partially replaced by Bagasse ash and $\mathrm{M}$ sand by slag sand with varied concentration. Concentration of Bagasse ash replaced in cement are $0 \%, 8 \%, 12 \%, 16 \%$, and $20 \%$, as for Manufactured sand the replaced percentage of slag sand is $0 \%, 15 \%, 30 \%, 45 \%$ and $60 \%$. The physical test of constitutes used in HPC has been carried out. The strength characteristics such as compression, tension and flexure are conducted for the curing period of 28 days. The result shows that, including Bagasse ash and slag in concrete increases the compressive strength up to a percentage concentration of $8 \%$ Bagasse ash and 15\% slag sand, any further increase in the concentration of Bagasse ash and slag sand would decrease the overall strength of concrete.
\end{abstract}

Key words: Bagasse ash; slag sand; high performance concrete compression; flexure; tension.

\section{INTRODUCTION}

According to American Concrete Institute, Concrete needs special combination of uniformity and performance requirements that cannot be achieved using regular constituents and traditional mixing, placing, and curing practices. High performance concrete (HPC) is intended to design and perform higher than nominal concrete in terms of its durability and strength $[1,2]$. The proportions of High-Performance Concrete (HPC) mixtures are designed and engineered towards providing high strength and durability, although composing of primarily the same materials as conventional concrete mixtures, necessary for the structural and environmental requirements of the project. The approximate compressive strength of High-strength concrete is more than or equal to 55 $\mathrm{MPa}$. This value of $55 \mathrm{MPa}$ is chosen, as it would require special care for production and testing of the concrete and this defined high strength value would require special structural design [3, 4, 5]. Contents of High-performance concrete would include one or more of cementitious materials namely Silica fume, ground granulated blast furnace slag or fly ash \& sometimes a superplasticizer. The term 'high performance' is somewhat pretentious because the basic feature of this concrete is that it's constituents and quantities are carefully chosen so as to have specifically appropriate properties that are intended use of structure viz high strength and low penetrability[6,7,8].

Hence, High-performance concrete (HPC) does not behaves differently when compared to nominal concrete as the composition of nominal and HPC are same $[9,10,11]$. The workability qualities, strength and durability are enhanced to a very high extent due to the use some admixtures and minerals viz Silica fume and Superplasticizer.

\section{CHARACTERIZATION OF MATERIALS}

The property of the materials is obtained from the experimental tests carried out according to IS codes for cement, bagasse ash, slag sand, manufactured sand (M-sand), $20 \mathrm{~mm}$ and $12 \mathrm{~mm}$ aggregates.

\section{A. Cement}

Birla super 53 grade of OPC is used as referred in the code IS: 12269-1987 the terms of tests as per IS-4031 part 11-1988. The tests are carried out and the properties of the cement are obtained.

\section{BAGASSE ASH}

Bagasse ash is used as replacement material for the cement. The bagasse ash is procured from the sugar factory in K.M Doddi. 


\section{FINE AGGREGATE}

The fine aggregate used in the concrete is M-sand and slag sand. The results obtained for partially replacement of M-sand and slag sand are depicted.

\section{MANUFACTURED SAND}

The manufactured sand is obtained from the local quarry. The properties have been studied according to IS: 2386-1963 Part 3 and IS: 383-1970. According to IS: 383-1970, sieve analysis is done and zone II is obtained. According to IS: 2386-1963 Part 3 , specific gravity, loose and dense bulk density. These tests are carried out and results as shown in the Table 1.

Table 1: M-Sand Properties

\begin{tabular}{|l|l|l|}
\hline Sl. No. & Properties & Result \\
\hline 1 & Specific gravity & $2.42 \mathrm{~g} / \mathrm{cc}$ \\
\hline 2 & Sieve analysis & Zone II \\
\hline 3 & Loose Bulk density & $1437.78 \mathrm{~kg} / \mathrm{m} 3$ \\
\hline 4 & Dense Bulk density & $1716.67 \mathrm{~g} / \mathrm{m} 3$ \\
\hline
\end{tabular}

\section{SLAG SAND}

The slag sand is obtained from Bellary in $50 \mathrm{~kg}$ bag. The properties have been studied according to IS 2386 1963, Part 3 and IS 383 1970. According to IS 383-1970, sieve analysis is done and zone II is obtained. According to IS 2386-1963, Part 3 , specific gravity, loose and dense bulk density. These tests are carried out and results as shown in the Table 2.

Table 2: Slag Sand Properties

\begin{tabular}{|c|c|c|}
\hline SI. No. & Properties & Result \\
\hline 1 & Specific gravity & $2.54 \mathrm{~g} / \mathrm{cc}$ \\
\hline 2 & Sieve analysis & Zone II \\
\hline
\end{tabular}

\section{COARSE AgGREgATE}

Coarse Aggregates passing $20 \mathrm{~mm}$ and $12 \mathrm{~mm}$ retaining conforming to IS 383- 1970 are obtained from the nearby quarry are used in the manufacture of concrete. The properties have studied according to IS 2386 Part 3-1963. The results are obtained as shown Table 3.

Table 3: Coarse Aggregate Properties

\begin{tabular}{|c|c|c|}
\hline Sl. No. & Properties & $\begin{array}{c}\text { Resul } \\
\mathrm{t}\end{array}$ \\
\hline 1 & Specific gravity & $2.74 \mathrm{~g} / \mathrm{cc}$ \\
\hline 2 & Sieve analysis & Zone II \\
\hline 3 & Loose Bulk density & $1489 \mathrm{~kg} / \mathrm{m} 3$ \\
\hline 4 & Dense Bulk density & $1617 \mathrm{~m} 3$ \\
\hline
\end{tabular}

\section{ADMIXTURE}

To attain the workability and required slump super plasticizer Conplast-420 is used according to IS 9103-1979, manifested by FOSROC chemicals.

\section{MIX PROPORTIONING}

The mix design is done as per IS 10262-2009. Design of mix is done for high performance of concrete using Bagasse ash and slag sand which are partially replaced for different percentage which depicted in the Table 4.

Table 4: Mix Design for HFC

\begin{tabular}{|c|c|c|c|}
\hline Sl. No & $\begin{array}{c}\text { Water-cement } \\
\text { ratio }\end{array}$ & \% of Fly ash & $\begin{array}{c}\text { \% of slag } \\
\text { sand }\end{array}$ \\
\hline 1 & 0.34 & 0 & 0 \\
\hline 2 & 0.34 & 8 & 15 \\
\hline 3 & 0.34 & 12 & 30 \\
\hline 4 & 0.34 & 16 & 45 \\
\hline 5 & 0.34 & 20 & 60 \\
\hline
\end{tabular}

\section{EXPERIMENTAL PROGRAMME}

The study on developing high performance concrete is done using Bagasse ash and slag sand partially replaced with cement and manufactured sand according to IS 10262-2009. Conplast- 420 superplasticizer $1 \%$ by weigh of cement is used for better workability.

The strength properties for the concrete mixes are compression strength, flexural strength and tensile strength are tested for 28days. The desired values were obtained by testing specimens of cubes of size $150 \times 150 \times 150 \mathrm{~mm}^{3}$ to measure compressive strength, each combination six in number, cylindrical specimen of size $150 \mathrm{~mm}$ diameter and height $300 \mathrm{~mm}$ were cast six in number of each combination to determine the split tensile strength and beam prism of 150 x $150 \times 1000 \mathrm{~mm}^{3}$ was cast of each six number in combination to study the flexural behavior of Bagasse ash and slag sand under pure bending test (Two point loading).

\section{RESULTS AND DISCUSSION}

Compression test: The result shows the compression strength of the concrete for partial replacement of Bagasse ash and slag sand. From the evaluation of results bagasse ash with $8 \%$ and slag sand by $15 \%$ shows high strength is $58.93 \mathrm{MPa}$. The weight of the mixes reduces as the replacement increases. As replacement increases strength decreases. Figure 1 shows a gradual decrease of compressive strength increased combination of bagasse ash and slag sand. 
Split tensile strength: The result shows the tensile the strength of the concrete for partial replacement of bagasse ash and slag sand. From the evaluation of results bagasse ash with $8 \%$ and slag sand by $15 \%$ shows high strength. The weight of the mixes reduces as the replacement increases. As replacement increases strength decreases as shown in Figure 2.

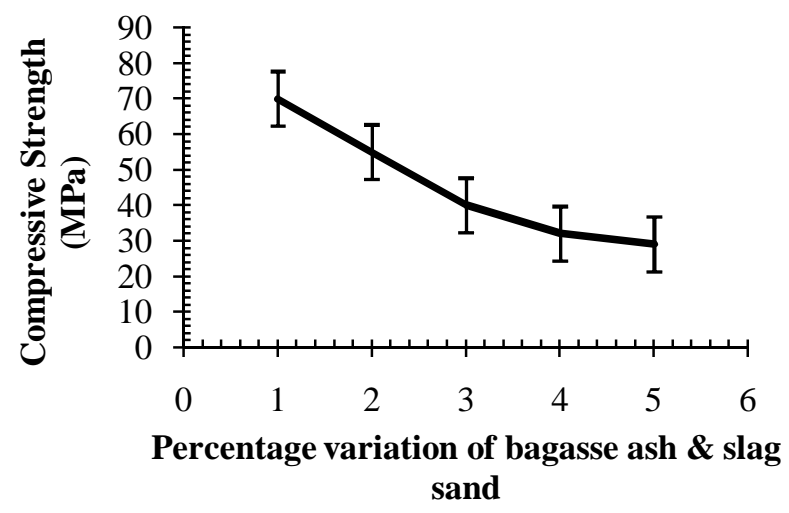

1. $0 \%$ bagasse ash \& $0 \%$ slag sand

2. $8 \%$ bagasse ash \& $15 \%$ slag sand

3. $12 \%$ bagasse ash \& $30 \%$ slag sand

4. $16 \%$ bagasse ash \& $45 \%$ slag sand

5. $20 \%$ bagasse ash \& $60 \%$ slag sand

Figure 1 : Compressive Strength for 28 Days for Different Percentage of Partial Replacement

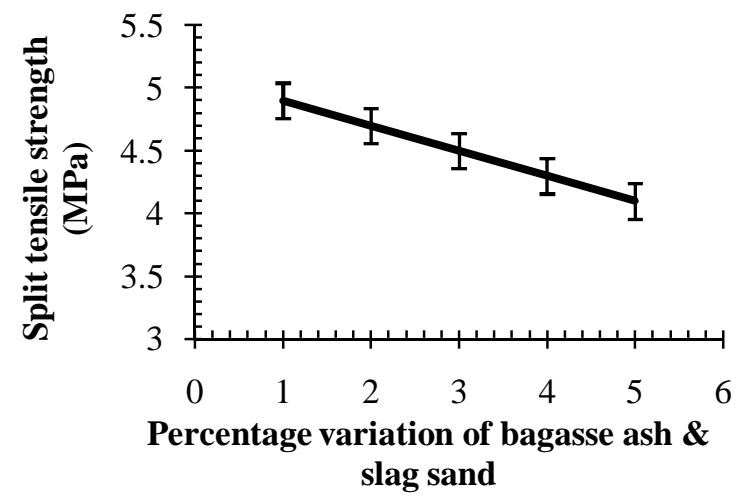

1. $0 \%$ bagasse ash \& $0 \%$ slag sand

2. $8 \%$ bagasse ash \& $15 \%$ slag sand

3. $12 \%$ bagasse ash \& $30 \%$ slag sand

4. $16 \%$ bagasse ash \& $45 \%$ slag sand

5. $20 \%$ bagasse ash \& $60 \%$ slag sand

Figure 2:- Split Tensile Strength for 28 Days for Different Percentage of Partial Replacement

Flexural strength: The result shows the flexural the strength of the concrete for partial replacement of bagasse ash and slag sand. From the evaluation of results bagasse ash with $8 \%$ and slag sand by $15 \%$ shows high strength that is as the weight of the of the mixes reduces as the replacement increases as shown in Figure 3. As replacement increases strength decreases.

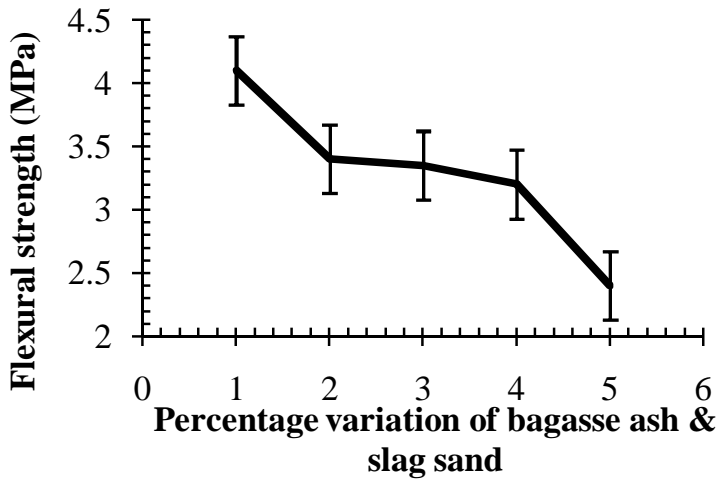

1. 0\% bagasse ash \& $0 \%$ slag sand
2. $8 \%$ bagasse ash \& $15 \%$ slag sand
3. 12\% bagasse ash \& 30\% slag sand
4. 16\% bagasse ash \& 45\% slag sand
5. 20\% bagasse ash \& $60 \%$ slag sand

Figure 3 : Flexural Strength for 28 Days for Different Percentage of Partial Replacement

\section{CONCLUSION}

In this paper, strength characteristics of concrete is computed by replacing $8 \%, 12 \%, 16 \% \& 20 \%$ bagasse ash by cement and $15 \%, 30 \%, 45 \%$ \& $60 \%$ slag sand with M-sand. Percentage increase in replacements such as bagasse ash and slag sand is directly proportional to decrease in workability of concrete. The following conclusions are drawn:

1. The compressive strength on concrete for $8 \%$ bagasse ash and 15\% slag sand replacement strength decreases by $19.18 \%$, for $12 \%$ bagasse ash and $30 \%$ slag sand replacement decrease in strength of $33 \%$, for $16 \%$ bagasse ash and $45 \%$ slag sand replacement and $20 \%$ bagasse ash and $60 \%$ slag sand replacement strength decreases between 50 to $60 \%$.

2. The flexural strength of concrete for $8 \%$ bagasse ash and $15 \%$ slag sand replacement strength decreases by $14.67 \%$, for $12 \%$ bagasse ash and $30 \%$ slag sand replacement decrease in strength of $15.67 \%$, for $16 \%$ bagasse ash and $45 \%$ slag sand replacement decrease in strength of $22.88 \%$ and $20 \%$ bagasse ash and $60 \%$ slag sand replacement strength increases by $39.80 \%$ than that of $16 \%$ bagasse ash and $45 \%$ slag sand.

3. Concrete's split tensile strength for $8 \%$ bagasse ash and $15 \%$ slag sand replacement a slight decrease in strength of $4.10 \%$, for $12 \%$ bagasse ash and $30 \%$ slag sand replacement decrease in strength of $7.18 \%$, for $16 \%$ bagasse ash and $45 \%$ slag sand replacement and $20 \%$ bagasse ash and 60\% slag sand replacement strength decreases between 10 to $20 \%$. As the replacement percentage increases strength of concrete reduces. 
4. The high performance characteristics are shown by $8 \%$ bagasse ash and $15 \%$ slag sand replacement for compressive strength.

\section{ACKNOWLEDGEMENT}

Authors acknowledge Management of Sri Venkateshwara College of Engineering for providing the best infrastructure of the laboratory, without which the work would have been incomplete. And graduating students for their support to conduct experiments.

\section{REFERENCES}

[1] Chintan M. Patel, N.N. Chinwala, "An experimental study on bagasses ash in high strength concrete" International Journal of Advance Research in Engineering, Science \& Technology, Volume 3 (5), 2016

[2] Ganesh Khatri, L. Aparna, P.Thrivikrama Reddy, “A replacement to sand -slag sand", International Journal of Engineering Technology Science and Research Volume 5(1), 2018

[3] T Murugesan, R. Vidjeapriya, A. Bahurudeen, "Sugarcane Bagasse Ash-Blended Concrete for Effective Resource Utilization Between Sugar and Construction Industries”, Sugar Tech, 2020 https://doi.org/10.1007/s12355-020-00794-2

[4] Yuxing Zhang et al, "Experimental study on the utilization of copper tailing as micronized sand to prepare high performance concrete", Construction and building materials, Vol. 244, 2020 https://doi.org/10.1016/j.conbuildmat.2020.118312

[5] K. Akhilesh Reddy, I. Siva Kishore, "Study on behaviour of partial replacement of cement with sugarcane bagasses ash for high strength concrete mix”, International Journal of Civil Engineering and Technology, Volume 8(1), 2017

[6] Mankare Ulka S \& Ajay.A.Hamne, "Experimental study on partial replacement of various wastes in concrete", International Journal of Modern Trends in engineering and Research, Volume 12, 2016

[7] Prashant, Modania, M R Vyawahare, "Utilization of Bagasses Ash as a Partial Replacement of Fine Aggregate in Concrete", Chemical, Civil and Mechanical Engineering Tracks of 3rd Nirma University International Conference on Engineering, Elsevier Ltd., 2013 https://doi.org/10.1016/j.proeng.2013.01.007

[8] U. Vamsi Mohan, K.Nagendra Prasad, S. Praveen Kumar Reddy, “ Studies on Strength Characteristics of Concrete by Partial Replacement of Sand with Granulated BlastFurnace Slag", Journal of Mechanical and Civil Engineering, Volume 12(5). 2015

[9] Vinícius N. Castaldelli , Jorge L. Akasaki, José L.P. Melges, Mauro, M. Tashima, Lourdes Soriano, María V. Borrachero, José, "Use of Slag/Sugar Cane Bagasses Ash (SCBA) Blends in the Production of Alkali-Activated Materials", Materials, Volume 6, 2013 https://doi.org/10.3390/ma6083108

[10]Vishnumaya L, Rekha Ambi, "Strength and durability of OFC-fly ash-sugarcane bagasses ash blended concrete", International Journal of Scientific \& Engineering Research, Volume 5(7), 2014

[11]Mohd Fakri Muda, Saffuan Wan Ahmad, Fadhluhartini Muftah, Mohd Syahrul Hisyam Mohd Sani, "Mechanical Behaviour of Mortar Made with Washed Bottom Ash as Sand Replacement", International Journal of Emerging Trends in Engineering Research, Volume 7 (9), 2019. 